\title{
Vancouver 1983: Indrukwekkend, maar twyfelagtig
}

\author{
DJC van Wyk
}

\begin{abstract}
Vancouver 1983: Impressive, but dubious

This article is a short summary of the constitution, course and content of the 6th General Assembly of the World Council of Churches which took place during 1983 in Vancouver, Canada. It is a short summary of the most important presentations, reports and declarations. The article is concluded with some critical remarks on the World Council of Churches in general and in particular on the Vancouver meeting
\end{abstract}

In sowel die Ned Hervormde Kerk as die ander Afrikaanse Kerke is nie baie notisie geneem van die sesde Algemene Vergadering van die Wêreldraad van Kerke nie. Daarom lyk 'n versoek van die Redaksie van die Hervormde Teologiese Studies om 'n greep uit die inhoud van hierdie byeenkoms te mak en mee te deel, sinvol. Uit die aard van die saak moet dit as baie oorsigtelik beskou word.

Bykans drie jaar het nou verloop na dié vergadering in Vancouver, Kanada. Groter afstand bied die moontlikheid tot meer objektiewe, betroubare waarneming, oordeel en perspektief.

Dit was in Desember 1985 vyf en twintig jaar na die Cottesloeberaad van die Wëreldraad van Kerke in Johannesburg en die Ned Hervormde Kerk se bedanking uit dié liggaam. Sou ons, nadat kennis geneem is van die Vancouver-vergadering, enige korreksie in ons standpuntinname van destyds wou suggereer of sou ons dit wou bevestig? Indien ons daarby wil staan, is ons dan seker dat ons teologiese formulerings nog afdoende antwoord bied op die huidige denke en werk van die Wêreldraad? Ons moet die invloed wat daar van dié liggaam in die wêreld uitgaan, nie onderskat nie. Op hierdie oomblik oefen die bevrydingsteologie van die Wêreldraad enorme invloed uit op die teologiese, kerklike en politieke denke en gebeure in Suid-Afrika.

Is die Wêreldraad van Kerke 'n siekteverskynsel van die twintigste eeu sodat ons afwesigheid daar van gesonde oordeel getuig? Of is ons onbetrokkenheid by diê geweldige stryd oor eenheid, vrede, geregtigheid en armoede ' $n$ teken van ongehoorsaamheid aan die Woord en 
selfverblinding? Om dié vrae opreg te beantwoord, kan ons Kerk en teologie geen skade doen nie.

\section{VOORBEREIDING TOT EN SAMESTELLING VAN DIE VERGADERING}

Om ' $n$ byeenkoms soos hierdie mooi in die visier te kry, is nie so eenvoudig nie. Dit moet inderdaad ' $n$ indrukwekkende gebeure wees. Maar waar en hoe praat dié vergaderings? Is dit net deur sy amptelike boodskap of ook deur sy verklarings en resolusies? Praat hy deur die voordragte wat gelewer word of ook deur die rapporte wat in die kleiner groepe aanvaar word?

Die vergadering in Vancouver is gehou vanaf 24 Julie tot 10 Augustus 1983. Gedurende 18 maande voor die vergadering het 79 ekumeniese spanne die meeste van die ledekerke besoek ten einde voorbereidings vir die byeenkoms te help tref. Die materiaal vir die vergadering is in groepe deurgewerk.

Uiteindelik sou gemiddeld meer as 4500 mense per dag op een of ander wyse aan die byeenkoms deelneem. Daar was 900 afgevaardigdes, 1500 joernaliste en 2000 waarnemers, gaste en besoekers, verteenwoordigend uit 301 ledekerke van die Wêreldraad. Daarvolgens word bereken dat die Wêreldraad nagenoeg 400 miljoen mense van oor die hele wêreld verteenwoordig. Die onderskeie wêrelddele was soos volg verteenwoordig: Noord-Amerika 158, Wes-Europa 152, Oos-Europa 142, Afrika 131, Asië 114, Midde-Ooste 53, Latyns-Amerika 30, Karibiese gebied 19, Australië en Nieu-Seeland 26, Suidsee 22. Wat denominasies betref, was die verteenwoordiging soos volg: Gereformeerd 176, Luthers 122, Oosters-Ortodoks 169, Anglikaans 89, Metodiste 95, Verenigdes 82, Baptiste 38, Moraviërs 11, Dissipels 13, Ou Katolieke 8, Onafhanklikes 6, Pentekostaliste 11, Kimbanguïste 6, Mar Thoma 3, Mennoniete 2, Broers 2 en ander 14. Verder was daar 15 gaste uit ander godsdienste wat aktief aan die byeenkoms deelgeneem het, van wie 5 die vergadering by geleentheid toegespreek het. Die tale waarin dié vergadering sy werk gedoen het, was Engels, Frans, Duits, Spaans, Russies en Grieks. Die verrigtinge is in elkeen van dié tale vertaal en deur middel van apparaat deurgegee sodat elkeen teenwoordig dit in een van dié tale kon volg. 'Not only the diversity of member churches, but also the diversity of the human family within and beyond the churches, was striking for all to behold' (Gill 1983: 8). 'A glorious patchwork' het een waarnemer die byeenkoms bestempel, en 'n ander een: 'a sociological impossibility'. 


\section{VERLOOP EN WERKWYSE}

Elke Algemene Vergadering van die Wêreldraad stel homself ten doel om te voldoen aan drie vereistes of kenmerke. In die eerste plek: As die mees verteenwoordigende byeenkoms van die ledekerke, is die vergadering 'n geleentheid om die verbond wat die kerke met mekaar gemaak het, te herbevestig en te vier. Die Wêreldraad sien homself in sy konstitusie as 'n gemeenskap van kerke wat Jesus Christus as God en Verlosser bely. 'The Assembly, therefore, is the time for the churches to renew their confession of Jesus Christ in the light of the challenges of the present day' (Gill 1983: 6).

In die tweede plek: Die Wêreldraad van Kerke is opgerig om die gemeenskaplike roeping van sy ledekerke ten opsigte van eenheid en sending, diens en vernuwing te dien. Tydens 'n Algemene Vergadering word oor die vordering van die werk op al dié terreine verslag gedoen. Vir dié doel van bespreking is die werk van die Vancouver-vergadering rondom agt temas ingedeel, soos deur die Sentrale Komitee na die Nairobi-vergadering aanbeveel.

In die derde plek: Die Algemene Vergadering is die hoogste konstitusionele besluitnemings- en regerende liggaam van die Wêreldraad. Dit handel oor rapporte en wys 'n Sentrale Komitee aan.

Die Sesde Algemene Vergadering is gehou op die kampus van die Universiteit van Brits-Columbië in Vancouver. Die sentrum van die byeenkoms was ' $n$ reuse-tent wat op die grasperke opgeslaan is. Die name van die 301 ledekerke is rondom die tent aangebring. In 'n deeglik voorbereide diensboek is die liturgiese materiaal, gebede, liedere en orde vir daaglikse godsdiensoefeninge in die oggend en aand uiteengesit. Daagliks is nagmaalvierings volgens verskillende tradisies gehou. Daarbenewens is elke middag 'n diens gehou. Daar was sewe groot liturgiese byeenkomste.

Behalwe 'n geweldige klem wat tydens dié vergadering gelê is op liturgie, spiritualiteit, erediens en gebed, was nog 'n uitstaande kenmerk die gebruik wat van 'n verskeidenheid simbole, veral uit die inheemse Kanadese kultuur, gemaak is. 'n Tipe van 'n hut, eie aan die oorspronklike inheemse bevolking, is tussen die bome op die terrein van die byeenkoms opgerig. Dit het gedien as plek van meditasie. Vir die hele duur van die byeenkoms het 'n 'gewyde vlam' in die hut gebrand, aan die begin aangesteek deur 'n verteenwoordiger van een van die oorspronklike stamme wat vroeër op dié terrein gewoon het. Aan die einde van die eerste week van die vergadering is ' $n$ totempaal, 15 meter hoog, op die terrein opgerig as deel van die verrigtinge tydens 
die Kanadese Inboorlingdag, 29 Julie. Dié paal het na afloop van die vergadering ' $n$ tuiste in die hoofkwartier van die Wêreldraad in Genève gevind.

Onder die 15 gaste uit ander godsdienste was daar 3 Hindoes, 4 Boeddhiste, 2 Jode, 4 Moslems, 'n Sikh en 'n spiritualis uit die geledere van die Kanadese inboorlinge. Op die terrein van die byeenkoms is ook 'n 'inter-geloof' (inter-faith) sentrum opgerig waarin 6 openbare programme oor ' $n$ 'inter-geloof'-tema aangebied is.

Die openingsdiens is op die oggend van Sondag 24 Julie gehou. Die rede by dié geleentheid is gevoer deur Pauline Webb, 'n Metodis uit Brittanje en voorsitter van die Beplanningskomitee. Tydens die openingsgeleentheid van 2 uur is, aansluitend by die tema-Jesus Christus die Lewe van die wëreld - simbole van lewe uit verskillende kulture na die altaar in die tent gebring.

Hoogtepunte tydens die byeenkoms was 'n reuse-nagmaalsviering op Sondag 31 Julie. Dit is gelei deur die aartsbiskop van Canterbury, Robert Runcie. Hy is bygestaan deur 'n Luteraan uit Denemarke, 'n Gereformeerde uit Indonesië, 'n Metodis uit Benin, 'n Baptis uit Hongarye, 'n Moraviër uit Jamaika en 'n predikant van die Verenigde Kerk van Kanada. Nog ' $n$ hoogtepunt was die herdenking van die verwoesting van Hiroshima op 6 Augustus. Benewens 'n rede deur die Algemene sekretaris, Philip Potter, en 'n openbare getuienis ten gunste van vrede en geregtigheid, was daar ook 'n nagwaak wat die hele nag van 5-6 Augustus gehou is. 'The vigil was maintained throughout the night. Thousands were stil there at midnight, when Bishop Desmond Tutu of South Africa appeared at the assembly for the first time and received a standing ovation. "If God be for us, who can be against us!" said the man who for so many simbolizes the Church's struggle for justice and reconciliation. Standing amidst so many of God's children, he reflected: "It is one of the most wonderful things to belong to the Church of God"' (Gill 1983: 11).

Gedurende die eerste en derde week van die vergadering is ' $n$ hele reeks sittings van die volle byeenkoms gehou. Die tweede week is afgewissel met byeenkomste in kleiner groepe. Tydens die byeenkomste van die groot-vergadering is geluister na die verslae van die Algemene Sekretaris en die voorsitter van die Sentrale Komitee, Edward Scott, Anglikaanse aartsbiskop van Kanada. Verder is diẻ sittings in beslag geneem deur voordragte na aanleiding van die tema en subtemas, onder andere deur Allan Boesak en Dorothee Sölle.

Dan was daar 65 kleiner groepe, elkeen bestaande uit ongeveer 20 
persone. Dié groepe het gedien as 'n soort tuisbasis waar geloofsgemeenskap en Bybelstudie beoefen is en waar mense met mekaar verskillende agtergronde en tradisies kon deel. Gedurende die tweede week was daar ook nog 'n verdere verdeling in 8 Onderwerpgroepe, bestaande uit 120 persone elk. Hier is studiewerk oor agt verskillende ekumeniese onderwerpe gedoen waarna rapporte deur elke groep aan die groot vergadering voorgelê is.

Tydens en na die vergadering is deur verskeie teenwoordiges ernstige kritiek teen die gehalte van sommige van hierdie rapporte uitgespreek.

\section{OPENINGSREDE: PAULINE WEBB}

Pauline Webb is 'n lekeprediker uit die Metodiste Kerk in Brittanje. As voorsitter van die Voorbereidingskomitee van die Vancouver-vergadering het sy op die eerste dag die openingsrede waargeneem. Haar rede is gebaseer op 1 Johannes 1: 1-4.

Om Christus te ontmoet, is om in kontak te kom met die ware bron en doel van lewe, lewe onvernietigbaar deur alle magte van sonde en dood. Die gemeenskap van gelowiges moet die medium wees waardeur God sy lewende Woord tot die wêreld kommunikeer.

Die eerste klem moet val op die lewende Woord. Die Woord van God is nooit net ' $n$ gesproke of geskrewe woord nie. Dit is altyd werklike gebeurtenis. Byvoorbeeld: Die openingsrede tot die Uppsala-vergadering van die Wêreldraad in 1968 sou deur Mar:in Luther King gehou word. 'But what we had seen and heard then and found so difficult to handle became God's living word to us and in the event we were all changed by it. The Programme to Combat Racism which emerged from the Assembly itself became a happening through which the world heard and saw what we were saying in opposition to racism far more eloquently than they had ever heard it in any of our resolutions. To some it was an offence, to some it was a word of life' (Webb 1983: 345).

En nou, hier by Vancouver, staan die Ekumene weer by 'n nuwe gebeure. Die sleutelwoord wat Johannes hier gebruik, is die woord koinōnia. Dié woord beteken 'om iets met iemand te deel'. Koinós, gemeenskaplik, het te doen met wat almal aangaan en is daarom verwant aan woorde soos kommunikasie en gemeenskap. Idios, daarenteen, het te doen met wat net die individu aangaan. Die woord idioot is hieraan verwant. Volgens die Grieke kon die individu slegs deel hê aan die volle lewe indien hy deel het aan die lewe van die volle gemeenskap. 
Om so 'n koinōnía met mekaar te kommunikeer, het die Vancouververgadering byeengekom. Daar is kommunikasie oor alle idiotiese grense wat die wêreld tussen mense opgerig het, heen. Hier word byeengekom om die Woord van die lewe te deel. Die lewende ervaring van koinōnía kom tot uitdrukking in die gesprekke in die wandelgange, aan die eettafels, deur die uitruil van foto's en geskenke. 'And as we do so, we shall find that every encounter with another life across the barriers of race and culture and religion is a new encounter, with the source of all life' (Webb 1983: 347).

Sedert die vorige vergadering is mensebloed vergiet in die strate van Soweto, in kampe in Beiroet, in die berge van Afghanistan, in Noordlerland, in Sentraal-Amerika. In die fanatisme en magspolitiek van ons tyd word menselewens asof in 'n spel vernietig. Deur die getuienis van martelare is die bloed van Christus vergiet: Aartsbiskop Luwum van Uganda, aartsbiskop Romero van El Salvador en vele ander.

\section{OFFISIËLE RAPPORTE}

Uit die offisiële rapporte van die voorsitter van die Sentrale Komitee en die Algemene Sekretaris, word hier volstaan met 'n kort uittreksel uit die verslag van die sekretaris, Philip Potter.

In sy rede sluit Potter aan by 1 Petrus 2: 4-5 en handel oor die kerk as 'n huis van lewende stene. Een vorige Algemene Vergadering van die Wêreldraad is in Noord-Amerika gehou, naamlik dié te Evanston in 1954. Baie meer as by Evanston is die Wêreldraad tans verteenwoordigend van mense van or die hele wêreld. Die wolk van vrees en wanhoop oor die wêreld is tans baie donkerder as in 1954. Die konfrontasie tussen Oos en Wes, Noord en Suid, asook die konflikte tussen die geslagte, rasse, klasse en godsdienste is tans hewiger en meer kompleks. Die oorlewing van die mensegeslag word daagliks bedreig.

'n Vergelyking met die Nairobi-vergadering van 1975 toon dat die werk van die Wêreldraad van Kerke egter ook goed gevorder het. Daar is kontak met ' $n$ baie wyer verskeidenheid mense en kerke. Daar is hard gewerk aan die eenheid van die kerk en die vernuwing van die mensheid. Menslike behoeftes is so wyd as moontlik tegemoetgekom. Solidariteit is betoon met die onderdruktes en die beroofdes. In situasies van konflik is gepraat en gehandel. So is die kerk volgens sy wesenlike aard deur die woestyn onderweg na die stad van God.

In so 'n diaspora-situasie en kerk is die eerste brief van Petrus geskryf. Die Wêreldraad moet tans besin oor wat dit beteken om in ' $n$ 
soortgelyke vyandige wêreldsituasie ' $n$ huis van lewende stene te wees, 'n lewende gemeenskap wat deel in geregtigheid en vrede. Soos vir die Christene van destyds, sê Petrus vir ons dat om Christus te bely, beteken dat daar ingegaan moet word in die lyding van Christus en in sy opstanding gedeel moet word. Maar om lewende stene te word, beteken dat gelowiges en gemeenskappe van gelowiges nie geïsoleerd, alleen en dood mag bly nie. Hulle word in 'n huis, 'n oikos, ingebou wat lewendig deur die Gees van God gemaak word.

Die woord 'huis' was vir die mense van die antieke Midde-Ooste ryk in betekenis. Dit dui op gemeenskap, volk, kultuur, lewenswyse, struktuur en agtergrond. ' $n$ Ware huis moet gebou word op dié kwaliteite wat sy inwoners in staat stel om as 'n gemeenskap en in gemeenskaplike welsyn, šălōm, te leef. 'Where these qualities are lacking the house cannot stand. Institutions and structures acquire a demonic character when people lose that strength of being, that clear integrity and sense of purpose which enable them to discern, correct and change their situation. There comes a time, therefore, when existing structures have to be destroyed in order that new structures, a new oikos, can be built up based on a new covenant and enabling people to be responsible for themselves and for one another before God (Jer 31:27-34). This is what Jesus meant when he said that the old temple would be destroyed in his crucifixion and that he would rebuild it in three days through his resurrection' (Potter 1983: 353).

Gelowiges wat lewende stene is, oorkom die skeidings van rassisme en word die ware menslike ras wat na die beeld van God geskape is. Nasionalisme met sy eksklusiwistiese benadering moet plek maak vir 'n gemeenskap wat diensbaar is aan God se bedoeling om alle nasies tot een huis te verenig. 'It is this image and understanding of the living house which has motivated the ecumenical movement. As is well known, the word ecumenical is derived from the Greek word oikoumé$n \bar{e}$, meaning the whole inhabited earth. It is a word which came into common use when Alexander the Great was conquering the world of the Middle East and beyond. The intention was that peoples should give up their cultural isolation and participate in a cosmopolitan life through which they would discover their true humanity. That was the oikoumén $\vec{e}$. When the Romans conquered the Hellenists, their rulers were hailed as lords and saviours of the oikouméne.... The ecumenical movement is therefore, the means by which the churches which form the house, the oikos of God are seeking so to live and witness before all peoples that the whole oikouméne may become the oikos of God through 
the crucified and risen Christ in the power of the life-giving Spirit' (Potter 1983: 354).

\section{VOORDRAGTE TEN OPSIGTE VAN DIE HOOFTEMA}

Soos gemeld, was die hooftema van Vancouver: Jesus Christus die lewe van die wêreld. Na aanleiding van dié tema is twee voordragte gehou. Een is gelewer deur Theodore Stylianopoulos, Nuwetestamentikus en priester van die Griekse aartsbiskop in Noord- en Suid-Amerika. Weens gebrek aan ruimte word hier verder slegs verwys na die tweede voordrag ten opsigte van die hooftema, naamlik dié van Allan Boesak. Hy spreek hom soos volg uit:

Geweld, hebsug en demoniese verwringing van menslike waardes verwoes steeds God se wêreld en volk. Ekonomiese eksploitasie neem eerder toe as af. Rassisme in Suid-Afrika en elders is soos altyd teuelloos. Omdat rassisme dikwels gekoppel word aan ideologieë oor nasionale veiligheid, het dit ' $n$ nuwe dekmantel van fatsoen gekry.

In Suid-Afrika is apartheid en onreg oppermagtig. Ongelykheid word deur die wet geheilig en rasse-onderskeid deur die teologie gewettig. Apartheid is met die steun van Westerse regerings sterker as ooit en die droom van regverdigheid en menslike waardigheid vir Suid-Afrika se Swart bevolking verder weg as ooit. In ons wêreld word nie die blye, hoopvolle geluid van die wêreld van die lewe gehoor nie. Nee, die wêreld is gesmoor deur die afskuwelike geluid van kanongebulder, deur die gegil van ons kinders en deur die konstante geskreeu van die magteloses: Hoe lank nog Heer?

Op te veel plekke sterf te veel kinders ' $n$ hongerdood en te veel mense verdwyn eenvoudig omdat hulle durf opkom vir menseregte en regverdigheid. Tog verseker die evangelie ons: Jesus Christus is die lewe van die wêreld. Dit beteken dat $\mathrm{Hy}$ ons bestem vir ' $\mathrm{n}$ lewe vol oorvloed, vreugde en betekenis. $\mathrm{Hy}$ is die Messias in wie se oë ons lewe kosbaar is. Maar dit is die probleem. Mag ons dit glo? Kan ons dit glo sonder om van ons geloof 'n eng, spirituele eskapisme te maak? Kan ons die sinisme van die realiteit vermy?

In die oorweging van hierdie vrae moet twee dinge onthou word. In die evangelie is die bevestiging dat Jesus Christus die lewe van die wêreld is, nooit ' $n$ triomfantlike kreet nie. Dis nie 'n leuse met mag en krag as basis nie. Dis ' $n$ bieg te midde van swakheid, lyding en dood. Dit is die rustige, omverwerpende vroomheid waarsonder die Christelike Kerk nie kan nie. Ten tweede moet onthou word dat hierdie versekering in die Bybel aan mense gegee word wat in hulle omstandighede 
die armes, onderdruktes en swakkes was. Daarvan is die geskiedenis van Jesus en die Samaritaanse vrou asook die Openbaring van Johannes' $n$ illustrasie.

Daarom, al lyk dit op die oomblik of die diktators, die magtiges en die vermoëndes die wêreld volledig onder kontrole het en of hulle arrogansie en mag geen remminge het nie, weet die kerk: Jesus Christus is die Heer van die geskiedenis, Heer van die lewe en sy waarheid sal die laaste woord hê. 'In the same way Christians in South Africa begin to understand that for us God's moment is brought together with our present reality, as we discern that the Church is called to an extraordinary courageous witness for the sake of the gospel; (Gill 1983: 225).

Vrede mag nie geskei word van geregtigheid nie. Mense uit Afrika weet nie wat kernwapens beteken nie, maar hulle weet wat honger en armoede beteken. Vrede moet nie net 'n Noord-Atlantiese aangeleentheid word nie. Ook in die Bybel word vrede en geregtigheid nooit van mekaar geskei nie. Vrede beteken nooit slegs die afwesigheid van oorlog nie, maar die daadwerklike aanwesigheid van geregtigheid.

\section{DOROTHEE SÖLLE}

Benewens die hooftema was daar verder voordragte en besprekings onder vier subtemas: Lewe, 'n geskenk van God; Lewe, oorwinnend oor die dood; Lewe in volheid; Lewe in eenheid. Van die voordragte wat in aansluiting by dié subtemas gelewer is, het dié van Dorothee Sölle die grootste aandag getrek.

Aan die begin van haar rede verklaar sy dat sy praat as ' $n$ vrou wat uit een van die rykste lande in die wêreld kom, ' $n$ land met 'n bloedige geskiedenis en wat na gas stink, 'n land wat op die oomblik die volste gelaai is met kernwapens.

Christus is die vertaling van God. Hy maak duidelik wie God is. Dit dui nie op ' $n$ religieuse imperialisme asof daar nie in ander godsdienste ander verklarings van God kan bestaan nie. Waarop dit wel dui, is ' $n$ onvoorwaardelike verpligting om ons met hierdie Jesus Christus in te laat omdat ons die lewe van die wêreld soek en nie die dood nie.

Christus het gekom sodat ons lewe in volheid kan hê. Maar die misdaad van verarming in 'n tegnologies-ontwikkelde wêreld, vernietig mense liggaamlik, geestelik en godsdienstig. Dit vergiftig die hoop en maak van die geloof ' $n$ karikatuur. Tussen Christus, wat die volheid 
van lewe vir alle mense simboliseer, en die verarmde mense, staan die sonde as uitbuiting van die rykes wat probeer om die beloftes van Christus tot niet te maak.

Ons dra by tot die plundering of die volheid van die lewe. Ons doen mee aan die opdrag van Christus of aan wat die dief met die wêreld wil. Solank ons slegs slagoffers of toeskouers is in die stryd vir geregtigheid, steun ons die dief en sy kriminele dade. Lewe in volheid is onmoontlik in afgedwonge armoede.

Maar ook in die ryk, eerste wêreld is daar weinig volheid van lewe, maar eerder 'n steeds wyer, grypende leegte. Nie materiële agteruitgang nie, maar psigiese leegte, sinloosheid en oppervlakkigheid staan tussen Christus en die middelklasse van die eerste wêreld. Ons is leeg, maar tog oorlaai met soveel oorbodige dinge. Daar is verband tussen die rykdomme wat ons besit en verbruik en die leegheid van ons bestaan.

So was daar iets grondig verkeerd met die ryk jongman uit die Nuwe Testament se idee van die ewige lewe. Hy meen: Ek het alles en mis nog net een ding, vervulling. Jesus keer egter die verwagting om: Jy het nie te min nie, maar te veel. In die middelklasse van die eerste wêreld word vandag gesoek na 'n nuwe spiritualiteit. Daar word gesoek na geestelike volheid naas die materiële verworwenhede. Maar Jesus verwerp hierdie vroom hoop. Die volheid van die lewe kom nie as jy al alles het nie. Ons moet eers leeg word ten behoewe van God se volheid.

Apartheid is nie maar ' $n$ politieke sisteem in ' $n$ Afrikaland nie. Apartheid is ' $n$ manier van dink, voel en lewe sonder om bewus te wees van wat om jou gebeur. Daar bestaan 'n manier van teologie bedryf wat die armes en die wat ekonomies uitgebuit is, nie aan die woord laat kom nie. Dit is die apartheidsideologie. Geld en geweld hoort bymekaar. Wie geld tot sy god gemaak het, moet veiligheid tot sy staatsideologie maak en bewapening tot sy politieke prioriteit.

Bomme vernietig die volheid van lewe wat Christus ons beloof het. Dit vernietig die lewe van die armes in materiële sin en die lewe van die rykes in geestelike sin. Ons kan die volheid van die lewe nie ervaar solank ons met die bom leef nie. Die bom is die belangrikste simbool van die ryk wêreld.

\section{TEMAS VIR DIE KERKE EN DIE WÊRELDRAAD}

Waar vorige Algemene Vergaderings Seksies gehad het, was daar op die Vancouver-vergadering temas en temagroepe. Agt temas is deur agt 
groepe van 120 persone elk in klein groepe bestudeer. Na die studie is aan die groot vergadering gerapporteer. Wanneer die rapporte na bespreking aanvaar is, is dit na die lidkerke vir verdere studie verwys.

Die agt temas was die volgende:

- Getuienis in 'n verdeelde wêreld.

- Stappe in die rigting van eenheid.

- Beweging in die rigting van gemeenskap.

- Genesing en meelewing.

- Konfrontasie met magte wat vrede en oorlewing bedreig.

- Stryd in diens van geregtigheid en menslike waardigheid.

- Christelike opvoeding.

- Geloofwaardigheid in kommunikasie.

Van die rapporte oor hierdie temas is na die groepe terugverwys. Tydens en na die byeenkoms is deur verskeie persone gekla oor die swak gehalte van die meeste van hierdie rapporte. Hier word volstaan met enkele relevante uitsprake wat in sommige van die rapporte na vore gekom het.

- Gekonfronteer met kulture met vreemde wêreld- en denkvorme, is Westerse sendelinge dikwels geneig om sodanige kulture te veroordeel as heidens en vyandig teenoor die evangelie. Dié sendelinge vergeet dat die evangelie self deur eeue-oue interaksie van verskillende kulture beïnvloed is en dat hulle juis besig is om ' $n$ kultuurgebonde Christelike verkondiging op ander af te dwing.

Daarom moet daar gewerk word aan 'n nuwe teologiese verstaan van kultuur. Op die ekumeniese agenda moet plek kom waar verskillende kulturele uitdrukkings van die Christelike geloof met mekaar in gesprek kan tree.

- Terwyl die uniekheid van die geboorte, lewe, dood en opstanding van Jesus Christus erken en bely word, word ook erken dat dit God self is wat werksaam is in die soektog na godsdienstige waarheid onder aanhangers van ander godsdienste. Dialoog is nie 'n verloëning van Christus nie, maar 'n geleentheid om teenoor mekaar en die wêreld te getuig in verhouding tot verskillende waarnemings van die laaste werklikheid.

- Sommige meen die soektog na uiterlike kerkeenheid is belangriker as pogings van die kerk om deur politieke betrokkenheid te help vorm aan 'n nuwe gemeenskap waar geregtigheid, vrede en versoening sal heers. Ander meen weer dat kerkeenheid sekondêr is ten 
opsigte van die kerk se politieke betrokkenheid. So 'n dualisme ten opsigte van kerkeenheid en vernuwing mag nie in die kerk of in die agenda van die Wêreldraad bestaan nie. Die Wêreldraad wil juis beklemtoon dat doop, nagmaal en amp tekens is van 'n kerk wat leef en werk vir'n nuwe mensheid.

- In Suid-Afrika en Namibië verhoed gewettigde rassisme die meerderheid mense om deel te hê aan politieke besluitnemingsprosesse wat hulle lewe en toekoms raak. Kerke moet bewegings en groepe wat hulle hierteen verset, ondersteun.

- Daar moet ' $n$ nuwe teologiese verstaan kom betreffende die verdeling van materiële bronne, gebaseer op geregtigheid en solidariteit met die armes. Die mens het die reg om in sekerheid en veiligheid te woon. Dit vereis ekonomiese en sosiale geregtigheid vir almal en die verdediging van lewe binne ' $n$ bestendige politieke raamwerk. Dit is wettig vir elke nasie om sy veiligheid te beskerm teen aanvalle van buite, sonder om die veiligheid van ander nasies in gevaar te bring.

Dié erkenning mag egter nie daartoe lei dat selfsugtige belange beskerm word en onreg gesanksioneer word onder die dekmantel van nasionale veiligheid, die bewaring van wet en orde, die verdediging van die demokrasie of die beskerming van die 'vrye wêreld' nie.

\section{GETUIENISSE, VERKLARINGS EN RESOLUSIES}

Die verskillende voordragte oor die tema en subtemas is telkens tydens die vergadering afgewissel deur getuienisse oor hoe Jesus Christus lewend en teenwoordig is in konkrete situasies in verskillende wêrelddele. Daarbenewens was daar ses algemene verklarings en vier meer spesifieke resolusies oor wêreldaangeleenthede. 'The making and breaking of human life anywhere and for whatever reason is the legitimate and necessary concern of Christ's Church: on that score the churches as they work together through their World Council have never had any doubts. ... But where to start? Where to stop? And how to select? The Sixth Assembly, like its predecessors, was in that quandary. Like them it will be charged by some with having said too much on too many issues and by others with having uttered too little on too few' (Gill 1983: 129).

Die Sentrale Komitee het by 'n vorige geleentheid kriteria neergelê waarvolgens ' $n$ seleksie gemaak kan word met die oog op verklarings en resolusies. Dit lui soos volg: 
'1. Areas and issues on which the WCC has had direct involvement and long-standing commitment;

2. emerging issues of international concern to which the attention of the churches should be called for action;

3. critical and developing political situations which demand the WCC to make known its judgment and lend its spiritual and moral voice;

4. expectations from the member churches that the WCC should speak;

5. to set a policy mandate for the WCC secretariat' (Gill 1983: 129).

Met hierdie kriteria in die hand, het Vancouver verklarings gemaak oor geregtigheid en vrede, menseregte, die internasionale voedseltekort, die Midde-Ooste, Suider-Afrika en Sentraal-Amerika. Resolusies is opgestel oor die toestand in Afghanistan, Ciprus, die Suidsee en die regte van inboorlinge in Kanada.

Die resolusie ten opsigte van Afghanistan lui soos volg:

'We note initiatives, including that of the non-aligned movement, for peaceful resolution of the conflict. We welcome specially the initiatives taken by the Secretary General of the United Nations for resolving the conflict, summarized as follows:

- an end to the supply of arms to the opposition groups from outside;

- creation of a favourable climate for the return of the refugees;

- guarantee of the settlement by the USSR, the USA, People's Republic of China, and Pakistan;

- withdrawel of Soviet troops from Afghanistan in the context of an overall political settlement, including agreement between Afghanistan and the USSR.

We support the Secretary General's current efforts and hope that the negotiations among the parties concerned will lead to a comprehensive settlement.

We believe that this would enable the Afghan people to follow freely their own path of development and to progress towards a more just society. We also believe that such an agreement would reduce tension in the region and also contribute to improvement of relations between the USA and USSR and of international relations in general.

Meanwhile, the WCC should continue to provide humanitarian assistance to the Afghan refugees' (Gill 1983: 161).

In die verklaring ten opsigte van Suider-Afrika word gesê dat Christus aan die kruis die grense van vyandigheid wat mense uiteenhou, afgebreek het (Ef 2: 14) en so vrede gevestig het. Apartheid bou egter 
opnuut grense op en vernietig die volheid van lewe in Christus. In so 'n situasie kan 'n kerk wat werklik begeer om kerk van Christus te wees en die evangelie van bevryding wil verkondig nie ' $n$ konfrontasie met die owerheid vermy nie. As 'n mens 'n Christen is, is dit onmoontlik om in Suid-Afrika nie te vra vir 'n radikale pohitieke, sosiale en ekonomiese omwenteling nie. Suid-Afrika word verder kras veroordeel oor sy optredes in Angola, Lesotho en Mosambiek en daar word op gesinspeel dat hy die toestand in Zimbabwe probeer destabiliseer.

\section{BOODSKAP UIT VANCOUVER}

In 'n amptelike boodskap het die Vancouver-vergadering hom aan die einde soos volg uitgespreek:

Ons verteenwoordig 400 miljoen mense uit 300 ledekerke. Meer vroue, jongmense en mense met gebreke het aan hierdie vergadering deelgeneem as tevore. Ons is bemoedig deur soveel wat opnuut tot martelaarskap geroep is.

In Amsterdam in 1948 is ooreengekom om bymekaar te bly. Sedertdien is ons geroep om saam te groei en saam te stry. Hier, onder die tema Jesus Christus die lewe van die wêreld, is ons geroep om saam te leef. In hierdie vergadering het ons dié lewe geproe en ervaar.

Ons aanbidding in ' $n$ groot tent het ons herinner aan die pelgrimsvolk van God. Gebede en lofliedere in soveel tale is teken van die lewe saam in een groot Christelike familie. Die deelname van gaste uit ander gelowe herinner aan die wye mensegemeenskap. Ons het geluister na die krete van miljoene wat daagliks veg om te oorleef, wat deur militêre mag vernietig word of deur die propaganda van die magtiges.

Hierdie vergadering wil die ekumeniese beweging se toewyding aan sy oorspronklike ideale opnuut bevestig.

- 'n Ekumeniese visie. Die Heer het vir die eenheid van sy kerk gebid as ' $n$ teken waardeur die wêreld tot geloof, vernuwing en eenheid gebring sou kon word. Sedert Nairobi was daar oral sigbare beweging in die rigting van sigbare kerkeenheid: nuwe verenigde kerke, dade van gemeenskaplike getuienis, plaaslike ekumeniese projekte.

- Sending en evangelisasie. Daarmee word bedoel die diep identifikasie met ander aan wie vertel kan word dat Jesus Christus die lewe van die wêreld is. Ons verkondiging moet vertaal word in elke taal en kultuur.

- Geregtigheid en vrede. Onreg ontken God se gawes van eenheid, gemeenskap en verantwoordelikheid. Volke, groepe en sisteme wat 
mag gebruik om mense te verdeel, het daardie mag lief. God deel mag. Hy gee dit aan elke mens. Wat nodig is, is 'n nuwe ekonomiese orde waar mag gedeel word, nie gegryp word nie. Onreg lei tot geweld. Die lewe wat God se goeie gawe is, moet bewaak word wanneer nasionale sekuriteit 'n verskoning word vir arrogante militarisme.

\section{ENKELE VERDERE KNELPUNTE EN KRITIESE AANTEKENINGE}

\subsection{Die verhouding met die Rooms-Katolieke Kerk}

Waarom is die Rooms-Katolieke Kerk nie lid van die Wêreldraad van Kerke nie? Dié vraag het tydens en na die Vancouver-vergadering weer sterk na vore gekom.

Die Wêreldraad het van die begin af duidelik gemaak dat hy oopstaan vir alle kerke om met behoud van sy eie teologie en kerkopvatting lid te word. Die enigste voorwaarde is dat die basis van die Wêreldraad onderskryf moet word en dat die kerkwees van ander kerke nie volledig ontken moet word nie.

Omdat die Roomse Kerk sedert die tweede Vatikaanse Konsilie homself nie meer in die volstrekte sin van vroeër as die enigste ware kerk van Christus beskou nie, word tans geoordeel dat dié kerk aan alle voorwaardes vir volle lidmaatskap van die Wêreldraad kan voldoen.

Die huidige verhouding met die Roomse Kerk is in die rapporte van Vancouver beskryf as een van groeiende, voortgaande samewerking. Hoewel die Roomse Kerk dus nie lid van die Wêreldraad is nie, het lede van dié Kerk reeds vir jare sitting in komitees van die Wêreldraad, byvoorbeeld dié vir Geloof en Kerkorde.

Sake wat formele lidmaatskap strem, is onder andere die organisasiestruktuur in die Roomse Kerk. Dié Kerk sien homself as 'n soort Wêreldbond van plaaslike kerke onder leiding van die biskop van Rome (Houtepen 1984: 26). As die biskop van Rome of 'n sinode van biskoppe op ' $n$ konsilie uitsprake maak, bind dit die lede. By die Wêreldraad is dit nie so nie. Die ledekerke van die Wêreldraad is nasionale kerke wat onafhanklik van mekaar is.

Nog 'n hindernis vir formele lidmaatskap van die Roomse Kerk is dat dié Kerk 800 miljoen lede het teenoor slegs 400 miljoen lede wat deur die 301 lidkerke van die Wêreldraad verteenwoordig word. Dit is dus moeilik om dié saak organisatories só te reël dat daar enersyds reg laat 
geskied word aan die getalsverhoudings sonder dat die Roomse Kerk andersyds die dominerende vennoot gemaak word.

\subsection{Evangelicals en ecumenicals}

Soos reeds aangetoon, het daar by Vancouver 'n geweldige klem geval op liturgie, erediens, spiritualiteit en gebed. Nog 'n kenmerk was die groot bydrae deur vroue en jongmense. Gepaard met hierdie faktore was daar die sterk klem op ervaring en belewing. Die Bybelstudie was so ingerig dat dit telkens moes uitloop op die vraag: Wat beleef jy self daaraan, wat beteken dit vir jou in jou eie kultuur? In die kleingroepe is ervarings met mekaar gedeel. In getuienisse is 'verskriklike' verhale aangehoor en met mekaar gedeel oor honger, armoede en onreg. Die verbondenheid van mense in een kerk is op ' $n$ nuwe wyse ervaar. Daar was die ervaring dat ' $n$ stroom van krag mense van oor die hele wêreld saambind in hulle soektog na geregtigheid. Mense uit alle wêrelddele het mekaar ontmoet en mekaar se sorge en verwagtings gedeel. Daar was ook die ervaring dat daar brûe geslaan is tussen Christene uit verskillende tradisies, asook Christene en mense uit ander godsdienste.

Die klem op liturgie en spiritualiteit is aangehelp deur die groeiende deelname van Ortodokses. Terselfdertyd het dit gelei tot 'n merkwaardige toenadering tussen die evangelicals en die ecumenicals. Die evangelies-gesindes het sterk waardering gehad vir die klem wat op die erediens geval het. Daar is deur hulle aangedring op ' $n$ meer beduidende meedoen in die ekumeniese beweging en om minder afwysend en krities teenoor die Wêreldraad te staan. Hulle enigste besorgdheid was of die Wêreldraad van Kerke genoeg erns maak met die sendingopdrag. Dit was slegs 'n klein groep evangelies-gesindes, veral onder leiding van prof Peter Beyerhaus uit Duitsland, wat skerp afwysend teenoor die Wêreldraad bly staan het.

\subsection{Sinkretistiese tendense}

Van die bedenklikste aspekte van die Vancouver-vergadering was sy eienaardige, onkritiese gebruikmaak van allerlei simboliek uit die heidendom. Wat het totempale, meditasie-hutte, heidense simbole van lig en heilige vlamme met die geloof in Christus te maak? Dat elke ontmoeting met ' $n$ ander mens en lewe oor die grense van ras, kultuur en godsdiens heen 'n ontmoeting met God self is, is nie waar nie en kan nie Bybels verantwoord word nie. 
Die deelname van 15 persone uit ander godsdienste is gesien as aanduiding dat die dialoogprogram van die Wêreldraad uiteindelik goed op dreef is. ' $n$ Groot konferensie waar daar oor die teologiese waardering van die ander godsdienste en oor hulle plek in God se plan met die mensdom gehandel sal word, is vir 1990 in die vooruitsig gestel. Daar sal besin word oor die teologiese basis, die teologiese agtergrond en die teologiese konsekwensies wat die ontmoeting met die ander godsdienste vir die kerk en die teologie het.

Hieruit kom ' $n$ verdere twyfelagtige trek in die Wêreldraad na vore. Die uitgangspunt is dat daar in die ontmoeting met mense van ander godsdienste die meeste uit die egte gesprek geleer kan word. Teologiese vrae kan later deurdink word (Mulder 1984: 21). Die gevolg is dat baie relativerende en sinkretistiese tendense reeds hulle weg na die Wêreldraad gevind het sedert die dialoogprogram in 1971 opgerig is. Nadat dié program dus 20 jaar aan die gang sal wees, sal daar eers teen 1990 besin word oor die teologiese basis, inhoud en implikasies wat dié gesprek vir kerk en teologie het!

\subsection{Eensydigheid van die Wêreldraad}

Die Wêreldraad van Kerke het dit tydens sy Vancouver-vergadering weer eens duidelik gemaak dat hy nie anders kan as om met woord en daad by allerlei wêreldkonflikte betrokke te wees nie. Dat hy in dié proses al meer die beeld en rol van 'n onrusstoker aanneem wat hom oral waar probleme broei, inmeng, ontgaan blykbaar die aandag van dié liggaam; so ook die feit dat hy 'n werktuig geword het in diens van die politieke oogmerke van lande uit die Derde Wêreld wat toenemend die werk van die Wêreldraad domineer. Die Wêreldraad het vandag die groot pleitbesorger vir die armes en veronregtes in die wêreld geword. Maar die gees van veroordeling, arrogansie en radikalisme wat baie van sy uitsprake asook dié van sy verteenwoordigers kenmerk, is tog onversoenbaar met die gesindheid waarmee Christus die saak van die armes behartig het.

Ondanks alle ontkennings, is die Wêreldraad erg eensydig. Na Vancouver is aan verteenwoordigers van dié liggaam gevra waarom SuidAfrika kras veroordeel word, terwyl Rusland met betrekking tot sy inval in Afghanistan, mild hanteer word. Die antwoord was dat toestande dáár dit vir die kerk en Christene in Rusland ondraaglik sou kon laat word indien daar te hard gepraat en geoordeel word. Maar dit, asook die feit dat Suid-Afrika so fel veroordeel word, is dan tog 'n erkenning dat toestande in Suid-Afrika só is dat die Wêreldraad en 
biskop Tutu en dr Boesak in Vancouver kon praat soos daar gepraat is sonder die gevaar van optrede of vervolging in Suid-Afrika. Dit kom neer op ' $n$ ontkenning van die toestand in Suid-Afrika waaroor dié land voortdurend veroordeel word.

Die Vancouver-vergadering van die Wêreldraad van Kerke moes, soos en selfs meer as sy voorgangers, 'n indrukwekkende byeenkoms wees. Hy het egter ook vele dubieuse kante. Die Wêreldraad se bemoeienis vir vrede, geregtigheid en die armes oortuig nie as egte, Bybelse bewoënheid nie. Daar is te veel simptome van skynheiligheid, eensydigheid, politiekery en ander siekteverskynsels. Die konklusie is dat dit vir die kerk en die teologie waardiger is om aan die ontvangkant as aan die uitdeel-kant van dié liggaam se dade te wees.

\section{Literatuurverwysings}

GILL, D 1983. Official Report VI Assembly World Council of Churches Vancouver Canada 24 July - 10 August 1983. Geneve: World Council of Churches.

HOUTEPEN, A 1984. Die Rooms-Katolieke Kerk en de Wêreldraad van Kerken. Rondom het Woord 26/3, 25-30.

MULDER, DC 1984. Dialoog met die Wêreldreligies en die Evangelicalen. Rondom het Woord 26/3, 20-24.

POTTER, P 1983. A House of Living Stones. The Ecumenical Review 35/4, 350-363.

WEBB, P 1983. The Word of Life. The Ecumenical Review 35/4, 343-349. 